Original Research

\title{
Effect of Stress Caused by Electromagnetic Stimulation on the Fluorescence Lifetime of Chlorophylls in Alfalfa Leaves
}

\author{
Agata Dziwulska-Hunek ${ }^{1 *}$, Marek Ćwintal², Agnieszka Niemczynowicz ${ }^{3}$, \\ Bożena Boroń ${ }^{4}$, Arkadiusz Matwijczuk ${ }^{1}$ \\ ${ }^{1}$ Department of Biophysics, University of Life Sciences, Lublin, Poland \\ ${ }^{2}$ Department of Plant Production Technology and Commodity Science, University of Life Sciences, Lublin, Poland \\ ${ }^{3}$ Department of Analysis and Differential Equations, Faculty of Mathematics and Computer Science, \\ University of Warmia and Mazury, Olsztyn, Poland \\ ${ }^{4}$ Chełkowski Institute of Physics, University of Silesia, Katowice, Poland
}

Received: 23 April 2018

Accepted: 12 July 2018

\begin{abstract}
The experimental material consisted of leaves obtained from 6- and 2-year-old alfalfa plants. Samples were obtained from a field experiment. One day prior to sowing, seeds were stimulated using He-Ne laser light with a surface power density of $6 \mathrm{~mW} \cdot \mathrm{cm}^{-2}-$ free-fall exposure (L) repeated three times; alternating magnetic field with $30 \mathrm{mT}$ induction and $30 \mathrm{~s}$ (P) exposure time; and a combination of laser light and magnetic field $(\mathrm{L}+\mathrm{P})$. The results of the stimulation treatments were referenced to non-stimulated samples (control $-\mathrm{K}$ ). The obtained values of fluorescence lifetime varied from 8.98 to $12.90 \mathrm{~ns}$ (t1) and from 3.84 to $5.14 \mathrm{~ns}$ (t2). The physical factors applied caused an extension of the lifetimes ( $\mathrm{t} 1$ and $\mathrm{t} 2$ ), as well as an increase in the chlorophyll a and carotenoid content in 6-year-old cv. Radius leaves, as compared to the control. Contrary observations (i.e., a decrease in the aforementioned indicators) were made for cv. Ulstar (old). In the case of magnetic field stimulation, the longest fluorescence lifetimes, the highest concentrations of chlorophyll a and carotenoids were noted for cv. Radius (old). The content of chlorophyll a was significantly higher in young Lucerne than in older plants.
\end{abstract}

Keywords: alfalfa, fluorescence of chlorophylls $a$, electromagnetic stimulation, photosynthetic pigments, seeds

*e-mail: agata.dziwulska-hunek@up.lublin.pl 


\section{Introduction}

In recent years, many various techniques of presowing material improvement have been practically applied, including a number of physical methods (e.g., laser light irradiation, magnetic field treatment, etc.) [14]. The positive effects of electromagnetic stimulation on seeds have been reported in various plant species, where it facilitated an improvement in germination, plant growth and development, as well as yield level and quality [5-9].

Alfalfa (Medicago sativa L.) is a perennial plant from the Fabaceae family. It is grown mainly for fodder [10], but it is also used as a human dietary supplement in the form of protein-xanthophyll concentrate (PX) and leaf extract EFL, both approved under Regulation (EC) No. 258/97 of the European Parliament and of the Council [11]. Alfalfa is characterised by very high nutritional value due to the presence of full-value protein and high carotenoid content. In addition, it has the ability to fix atmospheric nitrogen through symbiosis with rhizobia, which adds to its ecological value. Global alfalfa cultivation covers an area of approximately 32 million hectares [12-15]. In the regions where it is cultivated, problems are reported in many areas with regard to the growth and production of the Medicago species, largely in relation to global warming and long-term droughts occurring in many regions of the world [16].

Seed germination, emergence uniformity, and plant growth and development rates are key determinants of yield efficiency [17]. Alfalfa is a heliophyte, therefore light has a particularly strong effect on the intensity of its photosynthesis and its chlorophyll content [18-19]. Plant chlorophylls are mainly chlorophylls $a$ and $b$, typically occurring at the approximate ratio of 3:1 [20]. The content of chlorophylls in seeds changes with the degree of their maturity [21]. Light plays an important role in the processes of photosynthesis, i.e., the conversion of solar energy into chemical energy to be stored and used by the plant in the course of its development [22]. Solar radiation $(400-700 \mathrm{~nm})$ is the active photosynthetic radiation absorbed by chlorophylls $a$ and $b$ as well as carotenoids found in the photosynthetic antennae. From the same, energy is transferred to the reaction centres of photosystem II and photosystem I (PSII and PSI). The pigments absorb only a portion of the energy, as required to initiate the photochemical reactions involved in photosynthesis [23]. The remaining energy is converted into heat and emitted in the form of infrared and far infrared radiation (chlorophyll fluorescence) [24].

One of the techniques currently gaining popularity among researchers involves chlorophyll fluorescence measurements, which can be good indicators of the intensity of photosynthesis in plants [25]. Fluorescence is the emission of photons occurring due to the transition of electrons from the excited state $\left(\mathrm{S}_{1}\right)$ to their baseline energy (ground state $\left(\mathrm{S}_{0}\right)$. Fluorescence lifetime is defined as the average time of transition between the excited state and the ground state [26]. Fluorescence analyses are performed not only to test the efficiency

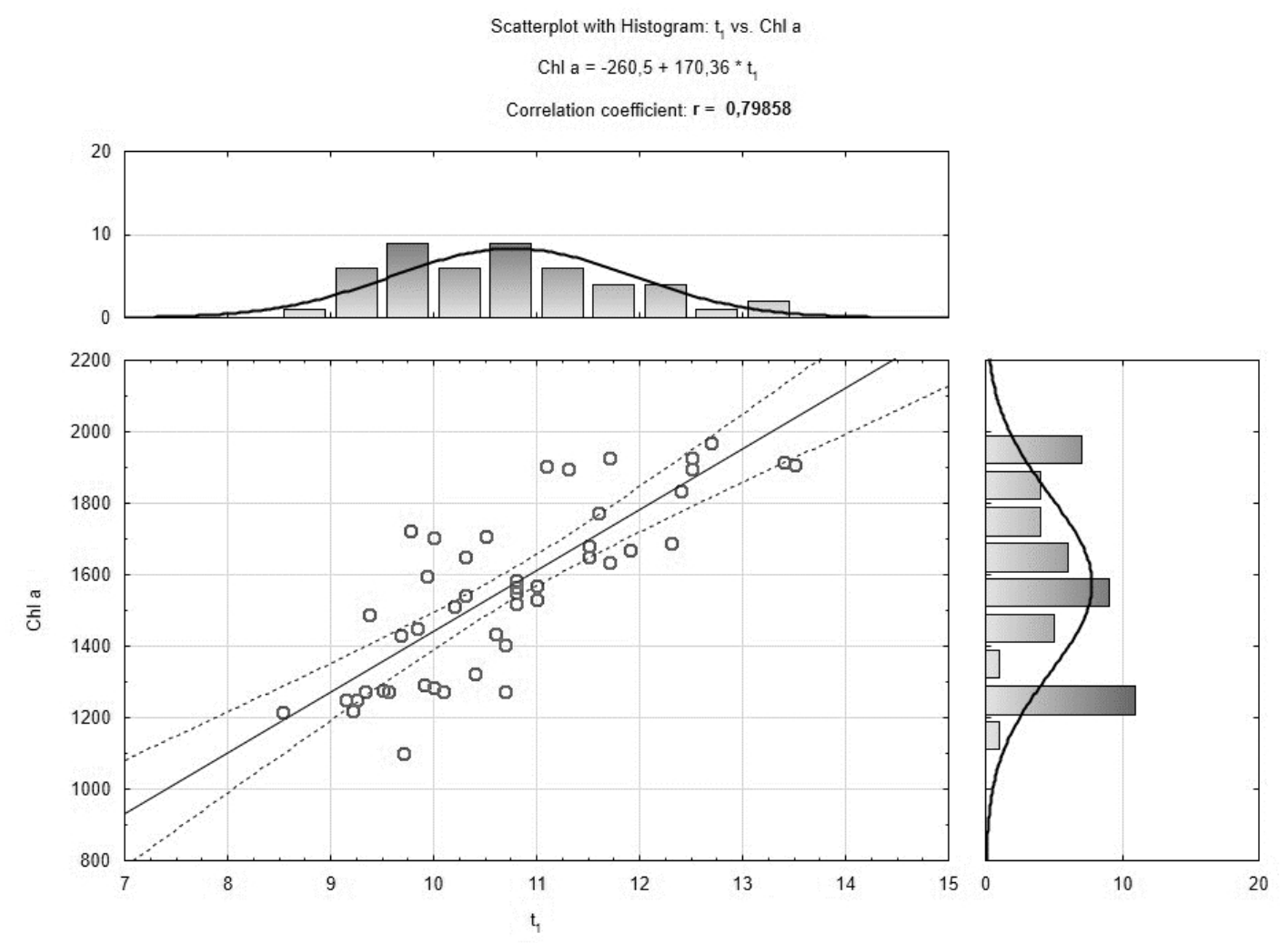

Fig. 1. Scattering plot with Histogram for correlation between fluorescence lifetime and Chl a. 


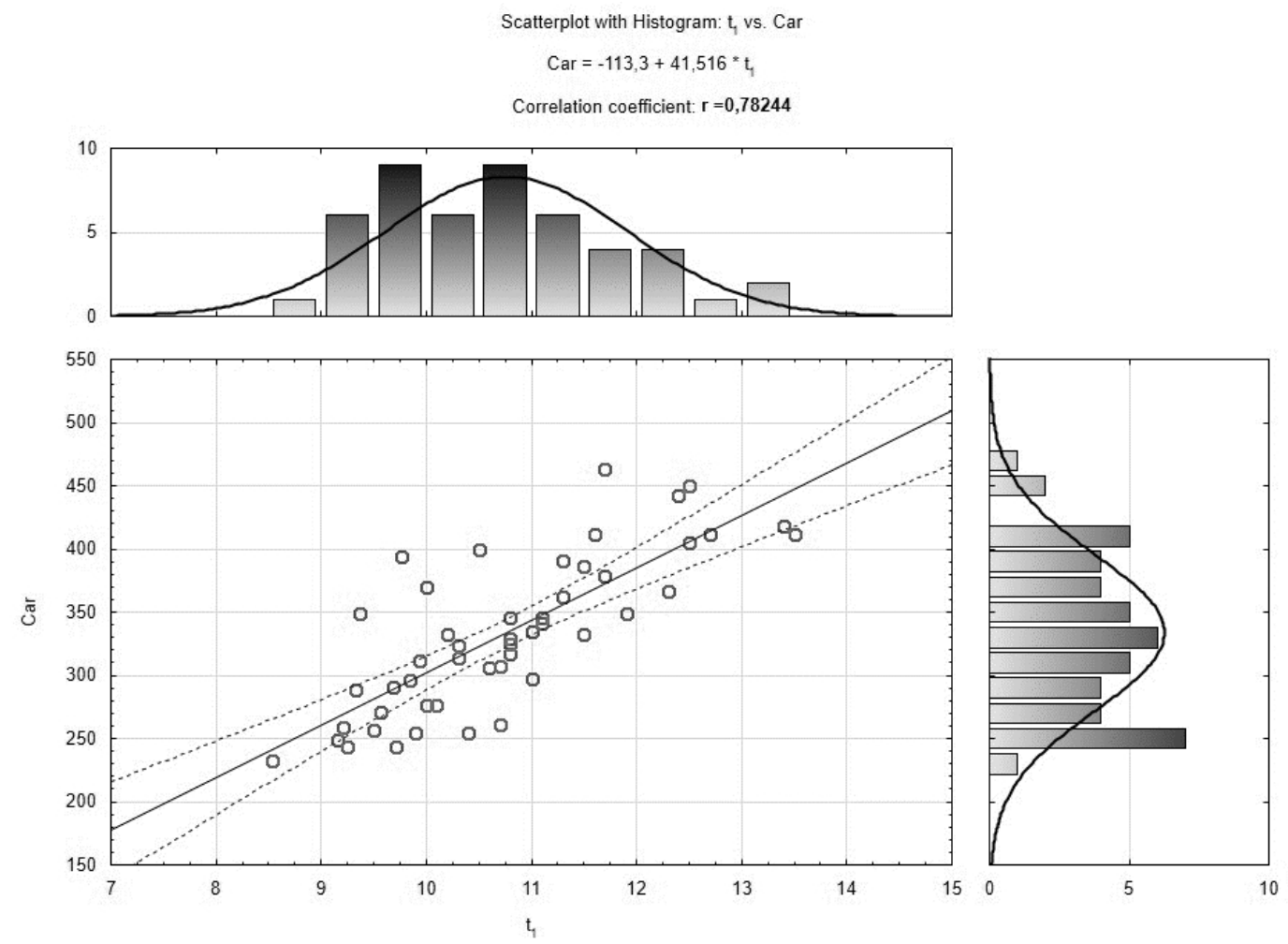

Fig. 2. Scattering plot with histogram for correlation between fluorescence lifetime and Carotenoid.

of photosystems, but also to provide an indicator of the physiological status of a plant organism [24, 27].

Plants are subjected to a variety of stress-inducting factors such as: high or low temperatures, high levels of insolation, water deficit, draught, non-optimal salinity, the presence of heavy metals, urbanization, etc. [2840]. The method allows for an assessment of the overall physiological status of plants, particularly for the purposes of optimising storage conditions of, e.g., vegetables, fruits, or flowers, as well as estimating yield ripeness for the purposes of consumption or processing $[24,27]$. Chlorophyll fluorescence measurements allow researchers to detect/analyse plant changes under conditions of, e.g., stress, which is extremely useful in the context of both plant selection/breeding and environmental protection. However, it should be noted that this method provides no information as to the nature of the stress factor.

The aim of the study presented herein was to determine the effects of stress caused by electromagnetic stimulation of seeds on the content of photosynthetic pigments and the chlorophyll fluorescence lifetime measured in the extracts of alfalfa and hybrid Lucerne leaves (from both old and young plants). So far, there have been few studies concerning the effects of applying electromagnetic stimulation to the seeds of perennial plants from the Fabaceae family. The idea of the study was to compare the concentration of photosynthetic pigments and the length of chlorophyll $a$ fluorescence lifetimes in 6-year-old alfalfa cv. The data were compared and analysed by correlation matrix and two-way ANOVA analysis. Significant correlations were obtained for all pigments and fluorescence lifetime. Ulstar and hybrid Lucerne cv. Radius plants with those observed in young, 2-year-old plants (in both cases grown from seeds subjected to stimulation before sowing).

\section{Material and Methods}

The experimental material consisted of leaves of 6- and 2-year-old alfalfa plants of two cultivars: Medicago sativa L. cv. Ulstar and Medicago x varia T. Martyn cv. Radius. Samples were collected from the third regrowth, at the onset of flowering, from a 2013 field experiment. The field experiment was conducted using the method of randomised blocks in four replicates (on plots with an area of $2 \mathrm{~m}^{2}$ ), at the Experimental Farm of the Department of Plant Production Technology and Commodity Science, University of Life Sciences, $\left(51^{\circ} 13^{\prime} 21.9^{\prime \prime} \mathrm{N}, 22^{\circ} 37^{\prime} 55.85^{\prime} \mathrm{E}\right)$, on soil classified as good wheat complex (soil quality class III a).

Alfalfa seeds with the moisture content of $12 \%$ were subjected to electromagnetic stimulation prior to sowing, respectively in 2008 and 2012, under the following treatment regimens: He-Ne laser light with surface power density of $6 \mathrm{~mW} \cdot \mathrm{cm}^{-2}$ - free-fall exposure (L) repeated three times; alternating magnetic field with $30 \mathrm{mT}$ induction and $\mathrm{f} 30 \mathrm{~s}(\mathrm{P})$ exposure time; and a combination of laser light and magnetic field $(\mathrm{L}+\mathrm{P})$. Non-stimulated seeds were used as the control 

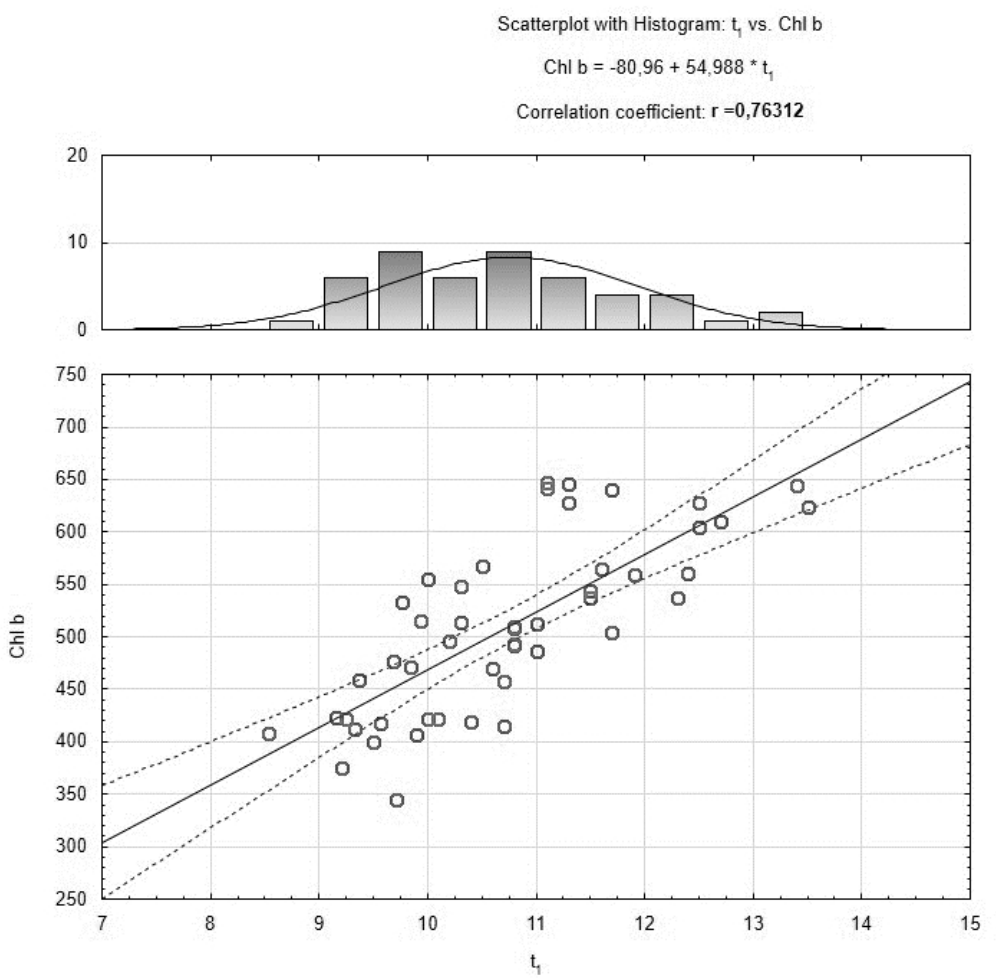

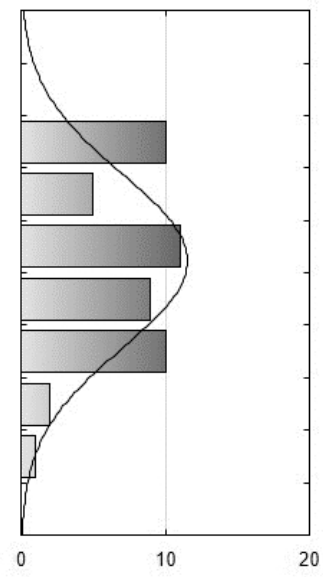

Fig. 3. Scattering plot with Histogram for correlation between fluorescence lifetime and Chl b.

(K). Stimulation with He-Ne laser light was conducted using an apparatus constructed by Koper and Dygdała [41], whose primary component is an He-Ne laser with the wavelength of $632.8 \mathrm{~nm}$. Seeds were irradiated with the laser beam during free fall. Magnetic field stimulation involved the use of an electromagnet. The structure and operating principle of the electromagnet was described by Muszyński et al. [42]. The process of stimulation was conducted one day prior to sowing.

Chlorophylls and carotenoids were isolated from the leaves in darkness with the use of acetone containing $0.01 \% \mathrm{w} / \mathrm{v}$ BHT (butylated hydroxytoluene) to prevent oxidation. UV-Vis spectra were measured using a double beam Carry Bio 300 spectrophotometer, while pigment concentrations were calculated on the basis of the procedure described by Lichtenthaler and Buschmann [43].

Fluorescence lifetimes were analysed in the extract of alfalfa leaves. Fluorescence lifetime measurements were made with the use of Chronos $\mathrm{BH}$ spectrofluorometer (ISS, USA) in time domain. For sample excitation, a $478 \mathrm{~nm}$ laser diode was used, with the impulse duration of 74 ps and output power of $103 \mathrm{~mW}$. The dispersing medium was milk solution diluted with deionised water. The fluorescence signal was acquired with the H7422P-50 photomultiplier (Hamamatsu, Japan) used as the detector. The signal levels from the sample and the dispersing solution were maintained at a similar level. Instead of an emission filter, a monochromator adjusted to $673 \mathrm{~nm}$ was used, which corresponds to the maximum of level of chlorophyll a fluorescence. A $2 \mathrm{~mm}$ wide entrance slit was used to direct the light from the sample to the monochromator, while an exit slit of the same width, placed behind the monochromator, directed the light beam to the photomultiplier. During the measurements, the collimator of light emitted by the sample was set to the magic angle (54.7 degrees) to avoid additional effects on the signal from anisotropy and rotational diffusion of sample molecules. Fluorescence decay curves were fitted using Vinci2 software supplied by the manufacturer of $\mathrm{BH}$. Measurements were conducted in a $10 \mathrm{~mm}$ quartz cuvette at room temperature.

\section{Data Fitting}

Fluorescence decay curves are a combination of three elements: (1) the function of sample response to exciting light (fluorescence), (2) the shape of exciting impulse, and (3) instrument function characteristic of a given instrument. The shape of exciting impulse (2) and instrument function (3) form the IRF signal (Instrument Response Function), which is the signal obtained once the exciting light passes through the dispersing medium - in our case the milk solution. The Vinci2 software automatically applies the contribution of the IRF function to the do total signal from the sample. The best results are obtained when the intensity of signals from the sample and from the dispersing solution is similar. The response signal from the sample is a composite of several (or one) exponential 
Table 1. Fluorescence lifetimes in extract from leaves in relation to electromagnetic factors, cultivar, and old and young alfalfa plants (ns).

\begin{tabular}{|c|c|c|c|c|c|}
\hline Cultivar & Physical factor & $\mathrm{t}_{1}$ & $\mathrm{t}_{2}$ & $\mathrm{f}_{1}$ & $\mathrm{f}_{2}$ \\
\hline \multirow{4}{*}{ Radius,old } & $\mathrm{C}$ & $8.98^{\mathrm{a}} \pm 0.38$ & $3.84^{\mathrm{a}} \pm 0.15$ & $0.44^{\mathrm{a}} \pm 0.04$ & $0.56^{\mathrm{a}} \pm 0.04$ \\
\hline & $\mathrm{L}$ & $9.43^{\mathrm{a}} \pm 0.26$ & $4.01^{\mathrm{a}} \pm 0.08$ & $0.42^{\mathrm{a}} \pm 0.03$ & $0.58^{\mathrm{a}} \pm 0.03$ \\
\hline & $\mathrm{F}$ & $9.84^{b} \pm 0.16$ & $4.17^{\mathrm{b}} \pm 0.09$ & $0.43^{\mathrm{a}} \pm 0.01$ & $0.57^{\mathrm{a}} \pm 0.01$ \\
\hline & $\mathrm{L}+\mathrm{F}$ & $9.63^{\mathrm{a}} \pm 0.34$ & $4.09^{\mathrm{b}} \pm 0.04$ & $0.41^{\mathrm{a}} \pm 0.02$ & $0.59^{\mathrm{a}} \pm 0.02$ \\
\hline \multirow{4}{*}{ Ulstar, old } & $\mathrm{C}$ & $11.17^{\mathrm{a}} \pm 0.81$ & $4.60^{\mathrm{a}} \pm 0.19$ & $0.40^{\mathrm{a}} \pm 0.04$ & $0.60^{\mathrm{a}} \pm 0.04$ \\
\hline & $\mathrm{L}$ & $9.93^{b} \pm 0.45$ & $4.19^{\mathrm{b}} \pm 0.10$ & $0.42^{\mathrm{a}} \pm 0.03$ & $0.58^{\mathrm{a}} \pm 0.03$ \\
\hline & $\mathrm{F}$ & $10.41^{\mathrm{b}} \pm 0.54$ & $4.36^{\mathrm{b}} \pm 0.14$ & $0.43^{\mathrm{a}} \pm 0.04$ & $0.57^{\mathrm{a}} \pm 0.04$ \\
\hline & $\mathrm{L}+\mathrm{F}$ & $10.50^{\mathrm{a}} \pm 0.30$ & $4.39^{\mathrm{b}} \pm 0.12$ & $0.42^{\mathrm{a}} \pm 0.02$ & $0.58^{\mathrm{a}} \pm 0.02$ \\
\hline \multirow{4}{*}{ Radius, young } & $\mathrm{C}$ & $11.17^{\mathrm{a}} \pm 0.12$ & $4.65^{\mathrm{a}} \pm 0.04$ & $0.44^{\mathrm{a}} \pm 0.01$ & $0.56^{\mathrm{a}} \pm 0.01$ \\
\hline & $\mathrm{L}$ & $11.90^{\mathrm{b}} \pm 0.44$ & $4.82^{\mathrm{a}} \pm 0.09$ & $0.41^{\mathrm{a}} \pm 0.02$ & $0.59^{\mathrm{a}} \pm 0.02$ \\
\hline & $\mathrm{F}$ & $11.00^{\mathrm{a}} \pm 0.44$ & $4.55^{\mathrm{a}} \pm 0.11$ & $0.43^{\mathrm{a}} \pm 0.02$ & $0.57^{\mathrm{a}} \pm 0.02$ \\
\hline & $\mathrm{L}+\mathrm{F}$ & $10.47^{\mathrm{b}} \pm 0.32$ & $4.38^{b} \pm 0.13$ & $0.43^{\mathrm{a}} \pm 0.03$ & $0.57^{\mathrm{a}} \pm 0.03$ \\
\hline \multirow{4}{*}{ Ulstar, young } & $\mathrm{C}$ & $12.53^{\mathrm{a}} \pm 0.85$ & $4.97^{\mathrm{a}} \pm 0.20$ & $0.43^{\mathrm{a}} \pm 0.05$ & $0.57^{\mathrm{a}} \pm 0.05$ \\
\hline & $\mathrm{L}$ & $11.19^{\mathrm{b}} \pm 1.29$ & $4.61^{\mathrm{b}} \pm 0.37$ & $0.46^{\mathrm{a}} \pm 0.09$ & $0.54^{\mathrm{a}} \pm 0.09$ \\
\hline & $\mathrm{F}$ & $12.90^{\mathrm{a}} \pm 0.53$ & $5.14^{\mathrm{a}} \pm 0.10$ & $0.41^{\mathrm{a}} \pm 0.03$ & $0.59^{\mathrm{a}} \pm 0.03$ \\
\hline & $\mathrm{L}+\mathrm{F}$ & $10.87^{b} \pm 0.12$ & $4.53^{\mathrm{b}} \pm 0.05$ & $0.44^{\mathrm{a}} \pm 0.01$ & $0.57^{\mathrm{a}} \pm 0.01$ \\
\hline Mean, Radius & & $10.30^{\mathrm{a}} \pm 1.00$ & $4.31^{\mathrm{a}} \pm 0.34$ & $0.43^{\mathrm{a}} \pm 0.01$ & $0.57^{\mathrm{a}} \pm 0.01$ \\
\hline Mean, Ulstar & & $11.19^{\mathrm{b}} \pm 1.03$ & $4.60^{\mathrm{a}} \pm 0.32$ & $0.42^{\mathrm{a}} \pm 0.02$ & $0.58^{\mathrm{a}} \pm 0.02$ \\
\hline Mean, old alfalfa & & $9.99^{\mathrm{a}} \pm 069$ & $4.21^{\mathrm{a}} \pm 0.24$ & $0.42^{\mathrm{a}} \pm 0.01$ & $0.58^{\mathrm{a}} \pm 0.01$ \\
\hline Mean, jung alfalfa & & $11.50^{\mathrm{b}} \pm 0.85$ & $4.71^{\mathrm{b}} \pm 0.25$ & $0.43^{\mathrm{a}} \pm 0.02$ & $0.57^{\mathrm{a}} \pm 0.02$ \\
\hline
\end{tabular}

Symbols: C - control, L - stimulation with He-Ne laser light with surface power density of $6 \mathrm{~mW} \cdot \mathrm{cm}^{-2}$ - irradiation three times in free fall, F - stimulation with alternating magnetic field with induction of $30 \mathrm{mT}$ and exposure time of $30 \mathrm{~s}, \mathrm{~L}+\mathrm{F}-$ combination of laser light and magnetic field.

Chl $a$ - chlorophyll $a$, Chl $b$ - chlorophyll $b$, Chl $a+b$ - sum of chlorophyll $a$ and $b$, Chl $a / b$ - ratio of chlorophyll $a$ to $b$,

Car - carotenoids.

$\mathrm{a} \rightarrow \mathrm{b}$ different letters in column - statistical differences between control and factors of electromagnetic stimulation,

between cultivars and between young and old alfalfa. Same letters - no statistical differences. \pm standard deviation.

functions whose exponents are used to calculate the fluorescence lifetime.

If fluorescence decay is a combination of several exponential curves, the reported result includes not only the calculated lifetimes (each exponential curve corresponds to a given lifetime), but also the percent contribution of the individual lifetimes to the signal as a whole, i.e., so-called fractions, which in turn can be correlated to the number of molecules with respective fluorescence lifetimes present in the solution. The goodness of fit of the theoretical curve to experimental data is expressed by the fitting parameter. It should be as close to 1 as possible but not lower than the same.

The results obtained were analysed statistically using STATISTICA 13.1 software. In order to assess the significance of differences of obtained values, results used two-way variance analysis (ANOVA) with POSTHOC Tukey test. For all variables, the significance level of $\mathrm{p}<0.05$ was adopted. Statistical differences were analysed between the respective cultivars, physical factor and lifetime $t_{1}$. All values were tested for normal distributions by Levene's test (Fig. 5). As we can see in Table 3, all three variables have essential influence $(p<0.05)$. The combination of two-way interactions were examined for the independent variables: interaction of "Cultivar x Physical Factor" (Fig. 4).

The correlation coefficients presented in Table 4 show the highest correlation coefficients, ranging from 0.763 to 0.799 . Positive coefficients between fluorescence lifetime and pigments explain the direction of the relationship. Scatter plots show correlation between two variables: lifetime and chlorophyll $a$ (Fig. 1), lifetime and chlorophyll $b$ (Fig. 3) and lifetime and carotenoids (Fig. 2). The regression equations and lines are shown in Figs 1-3. The best-fit regression was obtained as linear correlation. The coefficient for fluorescence lifetime 
Table 2. Content of photosynthetic pigments in extract from leaves in relation to electromagnetic factors, cultivar, and old and young alfalfa plants $\left(\mu \mathrm{g} \cdot \mathrm{g}^{-1}\right)$.

\begin{tabular}{|c|c|c|c|c|c|c|}
\hline Cultivar & Physical factor & Chl $a$ & Chl $b$ & Chl $a+b$ & $\mathrm{Chl} a / b$ & Car \\
\hline \multirow{4}{*}{ Radius, old } & $\mathrm{C}$ & $\begin{array}{c}1239.70^{\mathrm{a}} \\
\pm 19.27\end{array}$ & $\begin{array}{c}417.56^{\mathrm{a}} \\
\pm 8.04\end{array}$ & $\begin{array}{c}1657.26^{\mathrm{a}} \\
\pm 27.28\end{array}$ & $\begin{array}{l}2.97^{\mathrm{a}} \\
\pm 0.01\end{array}$ & $\begin{array}{c}241.51^{\mathrm{a}} \\
\pm 8.23\end{array}$ \\
\hline & $\mathrm{L}$ & $\begin{array}{l}1270.24^{a} \\
\pm 199.65\end{array}$ & $\begin{array}{l}393.05^{\mathrm{a}} \\
\pm 59.15\end{array}$ & $\begin{array}{l}1663.29^{a} \\
\pm 258.77\end{array}$ & $\begin{array}{l}3.23^{\mathrm{b}} \\
\pm 0.03\end{array}$ & $\begin{array}{l}283.59^{\mathrm{a}} \\
\pm 57.22\end{array}$ \\
\hline & $\mathrm{F}$ & $\begin{array}{l}1528.75^{\mathrm{b}} \\
\pm 152.31\end{array}$ & $\begin{array}{l}500.81^{b} \\
\pm 46.80\end{array}$ & $\begin{array}{l}2029.56^{b} \\
\pm 198.83\end{array}$ & $\begin{array}{l}3.05^{\mathrm{b}} \\
\pm 0.04\end{array}$ & $\begin{array}{l}319.49^{\mathrm{b}} \\
\pm 44.24\end{array}$ \\
\hline & $\mathrm{L}+\mathrm{F}$ & $\begin{array}{c}1278.05^{\mathrm{a}} \\
\pm 5.03\end{array}$ & $\begin{array}{c}417.31^{\mathrm{a}} \\
\pm 5.38\end{array}$ & $\begin{array}{c}1695.36^{\mathrm{a}} \\
\pm 9.89\end{array}$ & $\begin{array}{l}3.06^{\mathrm{b}} \\
\pm 0.03\end{array}$ & $\begin{array}{c}278.69^{\mathrm{a}} \\
\pm 9.20\end{array}$ \\
\hline \multirow{4}{*}{ Ulstar, old } & $\mathrm{C}$ & $\begin{array}{l}1739.15^{\mathrm{a}} \\
\pm 136,24\end{array}$ & $\begin{array}{l}578.48^{\mathrm{a}} \\
\pm 42.74\end{array}$ & $\begin{array}{l}2317.63^{\mathrm{a}} \\
\pm 178.90\end{array}$ & $\begin{array}{l}3.00^{\mathrm{a}} \\
\pm 0.02\end{array}$ & $\begin{array}{l}354.28^{\mathrm{a}} \\
\pm 33.98\end{array}$ \\
\hline & $\mathrm{L}$ & $\begin{array}{c}1297.42^{\mathrm{b}} \\
\pm 23.58\end{array}$ & $\begin{array}{c}408.08^{b} \\
\pm 9.65\end{array}$ & $\begin{array}{c}1705.50^{\mathrm{b}} \\
\pm 33.23\end{array}$ & $\begin{array}{l}3.18^{\mathrm{b}} \\
\pm 0.02\end{array}$ & $\begin{array}{c}255.46^{\mathrm{b}} \\
\pm 1.21\end{array}$ \\
\hline & $\mathrm{F}$ & $\begin{array}{c}1569.80^{\mathrm{b}} \\
\pm 27.73\end{array}$ & $\begin{array}{c}513.82^{\mathrm{b}} \\
\pm 1.62 \\
\end{array}$ & $\begin{array}{c}2083.62^{b} \\
\pm 27.99\end{array}$ & $\begin{array}{l}3.10^{\mathrm{a}} \\
\pm 0.05 \\
\end{array}$ & $\begin{array}{l}319.72^{\mathrm{a}} \\
\pm 12.59 \\
\end{array}$ \\
\hline & $\mathrm{L}+\mathrm{F}$ & $\begin{array}{l}1589.52^{\mathrm{a}} \\
\pm 105.88\end{array}$ & $\begin{array}{l}524.18^{\mathrm{a}} \\
\pm 38.28\end{array}$ & $\begin{array}{l}2113.70^{\mathrm{a}} \\
\pm 144.15\end{array}$ & $\begin{array}{c}3.03^{\mathrm{a}} \\
\pm 0.02\end{array}$ & $\begin{array}{l}359.38^{\mathrm{a}} \\
\pm 35.28\end{array}$ \\
\hline \multirow{4}{*}{ Radius, jung } & $\mathrm{C}$ & $\begin{array}{c}1901.23^{\mathrm{a}} \\
\pm 2.65\end{array}$ & $\begin{array}{c}645.12^{\mathrm{a}} \\
\pm 2.82\end{array}$ & $\begin{array}{c}2546.35^{\mathrm{a}} \\
\pm 3.22\end{array}$ & $\begin{array}{l}2.95^{\mathrm{a}} \\
\pm 0.01\end{array}$ & $\begin{array}{l}349.80^{\mathrm{a}} \\
\pm 11.28\end{array}$ \\
\hline & $\mathrm{L}$ & $\begin{array}{l}1748.15^{\mathrm{a}} \\
\pm 102.01\end{array}$ & $\begin{array}{l}543.15^{\mathrm{b}} \\
\pm 33.56\end{array}$ & $\begin{array}{l}2291.30^{\mathrm{a}} \\
\pm 133.79\end{array}$ & $\begin{array}{l}3.22^{\mathrm{b}} \\
\pm 0.07\end{array}$ & $\begin{array}{l}411.09^{b} \\
\pm 31.59\end{array}$ \\
\hline & $\mathrm{F}$ & $\begin{array}{l}1503.72^{b} \\
\pm 202.33\end{array}$ & $\begin{array}{l}487.16^{\mathrm{b}} \\
\pm 64.58\end{array}$ & $\begin{array}{l}1990.88^{b} \\
\pm 266.83\end{array}$ & $\begin{array}{l}3.09^{\mathrm{b}} \\
\pm 0.02\end{array}$ & $\begin{array}{l}305.87^{\mathrm{a}} \\
\pm 38.75 \\
\end{array}$ \\
\hline & $\mathrm{L}+\mathrm{F}$ & $\begin{array}{c}1370.78^{\mathrm{b}} \\
\pm 85.45\end{array}$ & $\begin{array}{l}449.43^{b} \\
\pm 25.04\end{array}$ & $\begin{array}{l}1820.21^{b} \\
\pm 110.47\end{array}$ & $\begin{array}{c}3.05^{\mathrm{b}} \\
\pm 0.02\end{array}$ & $\begin{array}{l}296.42^{\mathrm{b}} \\
\pm 17.68\end{array}$ \\
\hline \multirow{4}{*}{ Ulstar, jung } & $\mathrm{C}$ & $\begin{array}{c}1912.97^{\mathrm{a}} \\
\pm 15.01\end{array}$ & $\begin{array}{c}637.70^{\mathrm{a}} \\
\pm 8.55\end{array}$ & $\begin{array}{c}2550.67^{\mathrm{a}} \\
\pm 22.46\end{array}$ & $\begin{array}{l}3.00^{\mathrm{a}} \\
\pm 0.0^{3}\end{array}$ & $\begin{array}{l}443.83^{\mathrm{a}} \\
\pm 23.36\end{array}$ \\
\hline & $\mathrm{L}$ & $\begin{array}{c}1697.96^{b} \\
\pm 22.10\end{array}$ & $\begin{array}{c}538.46^{\mathrm{b}} \\
\pm 5.70\end{array}$ & $\begin{array}{c}2236.42^{b} \\
\pm 17.66\end{array}$ & $\begin{array}{l}3.15^{\mathrm{b}} \\
\pm 0.0^{7}\end{array}$ & $\begin{array}{l}382.22^{\mathrm{b}} \\
\pm 14.28 \\
\end{array}$ \\
\hline & $\mathrm{F}$ & $\begin{array}{c}1935.38^{\mathrm{a}} \\
\pm 32.00\end{array}$ & $\begin{array}{c}612.97^{\mathrm{b}} \\
\pm 9.23\end{array}$ & $\begin{array}{c}2548.35^{\mathrm{a}} \\
\pm 28.46\end{array}$ & $\begin{array}{c}3.16^{\mathrm{b}} \\
\pm 0.09\end{array}$ & $\begin{array}{c}409.53^{\mathrm{b}} \\
\pm 3.50 \\
\end{array}$ \\
\hline & $\mathrm{L}+\mathrm{F}$ & $\begin{array}{c}1537.56^{\mathrm{b}} \\
\pm 24.22\end{array}$ & $\begin{array}{c}490.71^{\mathrm{b}} \\
\pm 4.16\end{array}$ & $\begin{array}{c}2028.27^{b} \\
\pm 26.31\end{array}$ & $\begin{array}{l}3.13^{\mathrm{b}} \\
\pm 0.04\end{array}$ & $\begin{array}{l}314.45^{\mathrm{b}} \\
\pm 16.30\end{array}$ \\
\hline \multicolumn{2}{|c|}{ Mean, Radius } & $\begin{array}{l}1480.08^{\mathrm{a}} \\
\pm 241.05\end{array}$ & $\begin{array}{l}481.70^{\mathrm{a}} \\
\pm 82.84\end{array}$ & $\begin{array}{l}1961.78^{a} \\
\pm 322.62\end{array}$ & $\begin{array}{c}3.08^{\mathrm{a}} \\
\pm 0.10\end{array}$ & $\begin{array}{l}310.81^{\mathrm{a}} \\
\pm 51.35\end{array}$ \\
\hline \multicolumn{2}{|c|}{ Mean, Ulstar } & $\begin{array}{l}1659.97^{\mathrm{a}} \\
\pm 209.45\end{array}$ & $\begin{array}{l}538.05^{\mathrm{a}} \\
\pm 72.79\end{array}$ & $\begin{array}{l}2198.02^{\mathrm{a}} \\
\pm 281.44\end{array}$ & $\begin{array}{l}3.09^{\mathrm{a}} \\
\pm 0.07\end{array}$ & $\begin{array}{l}354.86^{\mathrm{a}} \\
\pm 59.07\end{array}$ \\
\hline \multicolumn{2}{|c|}{ Mean, old alfalfa } & $\begin{array}{l}1439.08^{\mathrm{a}} \\
\pm 189.76\end{array}$ & $\begin{array}{l}469.16^{\mathrm{a}} \\
\pm 68.50\end{array}$ & $\begin{array}{l}1908.24^{\mathrm{a}} \\
\pm 257.66\end{array}$ & $\begin{array}{c}3.08^{\mathrm{a}} \\
\pm 0.09 \\
\end{array}$ & $\begin{array}{l}301.52^{\mathrm{a}} \\
\pm 43.67\end{array}$ \\
\hline \multicolumn{2}{|c|}{ Mean, young alfalfa } & $\begin{array}{l}1700.97^{b} \\
\pm 212.76\end{array}$ & $\begin{array}{l}550.59^{\mathrm{b}} \\
\pm 74.12\end{array}$ & $\begin{array}{l}2251.56^{b} \\
\pm 285.39\end{array}$ & $\begin{array}{l}3.09^{\mathrm{a}} \\
\pm 0.09\end{array}$ & $\begin{array}{l}364.15^{\mathrm{b}} \\
\pm 55.55\end{array}$ \\
\hline
\end{tabular}

Explanations as in Table 1

(either lifetime and chl b) is in this case close to the correlation.

\section{Results and Discussion}

It is well known that the effect of stress has a negative influence on the growth process of plants. Representative examples of environmental stressors experienced by plants can include rapid change of climate (drought, temperature, wind, change of insolation) and soil conditions (enzymes in structure of soil), tainted air, heavy metal, noise, etc. [30-34] Therefore, leaves are important markers to determine the conditions of plant growth.

Alfalfa leaves contain chlorophylls and carotenoids, which emit fluorescence at various wavelengths. Chlorophyll fluorescence in leaves is an indicator of the 


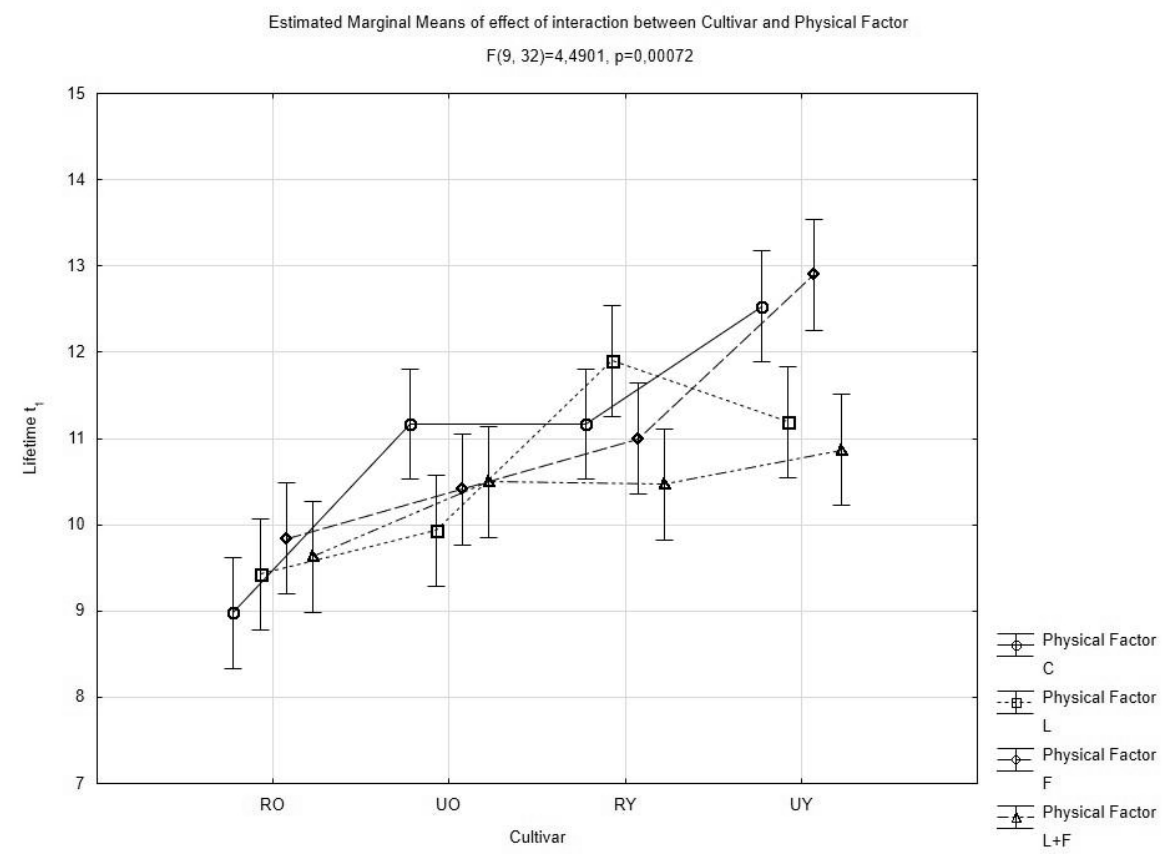

Fig. 4. Estimated marginal means of effect of interaction between cultivar and physical factor.

efficiency of photosynthesis, which can vary between respective plans for variety of reasons, e.g., due to environmental factors [44].

The study determined the mean lifetimes of two forms, $t_{1}$ and $t_{2}$, obtained from the tested sample, as well as the respective percentages of the same, $f_{1}$ and $\mathrm{f}_{2}$, relative to the applied electromagnetic stimuli, particular alfalfa cultivars, and the number of years since the stimulation (old and young plants, respectively 6 and 2 years old) (Table 1). The mean fluorescence lifetimes observed in the study varied, for $t_{1}$ between 8.98 and $12.90 \mathrm{~ns}$, and for $\mathrm{t}_{2}$ between 3.84 and $5.14 \mathrm{~ns}$, at the respective ratios: $\mathrm{f}_{1}$ from 40 to $46 \%$ and $\mathrm{f}_{2}$ from 54 to $60 \%$. For cv. Radius (old plants) longer decay times were noted for all the combinations of electromagnetic stimulants relative to the relevant control treatment, with the longest mean times $t_{1}$ and $t_{2}$

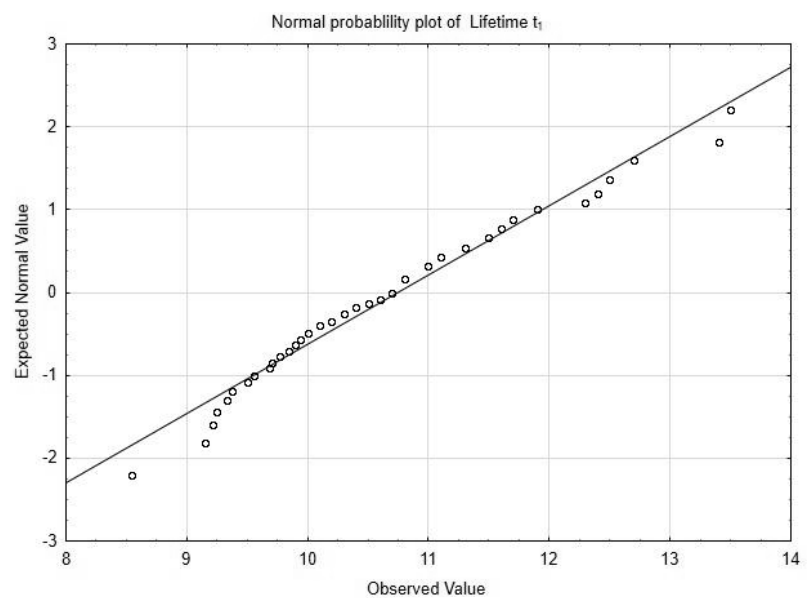

Fig. 5. Normal probability plot of lifetime $t_{1}$. observed for the alternating magnetic field treatment. The increase was significant and amounted to $9.6 \%$ and $8.5 \%$, respectively. In the case of cv. Ulstar (old plants), the opposite was observed, i.e., a reduction of the relevant durations.

Sowinska et al. [45] studied mean lifetimes in relation to the time of day, and the values varied within the range of 0.42 to $1.21 \mathrm{~ns}$ for poplar and, relative to the width of the camera slit, 0.54 to $0.62 \mathrm{~ns}$ (poplar), 0.42 to $0.54 \mathrm{~ns}$ (pine), and 0.20 to $0.83 \mathrm{~ns}$ (Catalpa an ornamental tree). In another study the authors analysed the fluorescence lifetimes in healthy and contaminated tobacco leaves and reported the presence of three fluorescence lifetimes in any given leaf, e.g., for a healthy leaf these were $t_{1}=0.33 \mathrm{~ns}, \mathrm{t}_{2}=0.73 \mathrm{~ns}$, and $t_{3}=3.02 \mathrm{~ns}$. The share of time $\mathrm{t}_{3}$ was very small $(0.002)$ in relation to the other times. Overall, the mean fluorescence lifetimes, depending on the filter used at a given wavelength, varied between 0.07 and 0.559 ns [46].

The study analysed the changes of fluorescence lifetimes in winter wheat leaves inhibiting the activity

Table 3. ANOVA results for the responses studied in the 2 factorial model.

\begin{tabular}{|c|c|c|c|c|}
\hline Source & $\begin{array}{c}\text { Sum of } \\
\text { squares }\end{array}$ & $\begin{array}{c}\text { Mean } \\
\text { square }\end{array}$ & F-test & p-value \\
\hline Cultivar & 37,273 & 12,424 & 41,61 & 0,000000 \\
\hline Physical Factor & 3,529 & 1,176 & 3,94 & 0,016861 \\
\hline $\begin{array}{c}\text { Cultivar x Physical } \\
\text { Factor }\end{array}$ & 12,066 & 1,341 & 4,49 & 0,000722 \\
\hline Error & 9,554 & 0,299 & & \\
\hline
\end{tabular}


Table 4. Correlation coefficients.

\begin{tabular}{|c|c|}
\hline & $\mathrm{t}_{1}$ \\
\hline $\mathrm{t}_{1}$ & 1 \\
\hline $\mathrm{Chl} a$ & 0,798576 \\
\hline $\mathrm{Chl} b$ & 0,763122 \\
\hline $\mathrm{Car}$ & 0,782439 \\
\hline
\end{tabular}

of the herbicide. A significant extension of the lifetimes was observed with the reported value of 2000 ps when compared to $560 \mathrm{ps}$ in the control group. Extension of fluorescence lifetimes was also observed in other combinations, depending on the factor used [47].

Chlorophyll $a$ is the main pigment responsible for photosynthesis, while chlorophyll $b$ and carotenoids are accessory pigments. A decrease in chlorophyll concentration may result in diminished photosynthetic activity, which in turn may adversely affect the rate of plant growth [48, 49]. The intensity of fluorescence depends on the current number of excited chlorophyll molecules. A decrease in fluorescence intensity may be related to the participation of solar energy in metabolic reactions or the processes of energy dissipation in the form of heat [27]. Table 2 presents the photosynthetic pigment content of the leaf extract relative to the respective electromagnetic factors, cultivars, and age of alfalfa plants. Concentrations of chlorophyll $a$ varied between $1239.70 \mu \mathrm{g} \cdot \mathrm{g}^{-1}$ (C, Radius, old) and $1935.38 \mu \mathrm{g}^{-1} \mathrm{~g}^{-1}$ (P, Ulstar, young). Notably, the highest content of chlorophylls $a$ and $b$ was observed after alternating magnetic field stimulation in alfalfa cv. Radius - old, where the same increased by $23 \%$ and $20 \%$, respectively, relative to the control group. With the exception of cv. Radius (old plants), in most of the remaining treatments, a decrease was noted in the concentration of chlorophylls $a$ and $b$, and carotenoids, as compared to the control. In the case of carotenoids, the most significant increase, by about $32 \%$ relative to the control, was noted in cv. Radius, old, samples subjected to alternating magnetic field stimulation, similarly to chlorophylls $a$ and $b$. In a study by Sujak et al. [14], the reported content of chlorophylls $a$ and $b$ and of carotenoids in alfalfa subjected to physical factors was varied and included both positive and negative relative to the control. An increase in the content of those pigments was noted only in the case of cv. Legend under all stimulation treatments.

Depending on light intensity, the concentrations of chlorophylls $(a, b, a+b)$ in fern leaves varied from 1.14 to $1.50 \mathrm{mg} \cdot \mathrm{g}^{-1}$, from 0.64 to $0.96 \mathrm{mg} \cdot \mathrm{g}^{-1}$, and from 1.78 to $2.47 \mathrm{mg} \cdot \mathrm{g}^{-1}$, respectively [50]. A study on old and young Arabidopsis thaliana ecotype Columbia plants conducted by Nozue et al. [51] revealed higher levels of chlorophyll a, b, and $\mathrm{a}+\mathrm{b}$ in mature plants, when compared to their younger counterparts.

A higher content of chlorophyll $a$ was noted in cv. Ulstar compared to cv. Radius, but the difference was not significant. On the other hand, a significant difference was found between old and young alfalfa plants, with the young alfalfa returning decidedly higher concentrations of chlorophyll $a$ when compared to the old plants. In a study on the effect of a constant magnetic field on the content of chlorophyll $a$ in lupine, an increase of $28 \%$ was reported relative to the control [52].

The content of total chlorophylls in soybean after the application of particular growth regulators as well as relative to the respective cultivars, developmental stages or years, varied from 638 to $1578 \mu \mathrm{g} \cdot \mathrm{g}^{-1} \mathrm{f}$.m, and the corresponding levels of carotenoids varied from 323 to $991 \mu \mathrm{g} \cdot \mathrm{g}^{-1}$ f.m [53].

Under saline stress, chlorophyll $a$ and $b$ as well as carotenoid content in bean was significantly reduced [54]. Phosphorus deficiency caused a reduction of the chlorophyll concentration in soybean, but did not affect the level of carotenoids [46].

Other stimulating factors (chemical), such as, e.g., salts, caused an increase in the chlorophyll content of white clover leaves [55] and certain alfalfa cultivars [12]. In another study, no significant increase in the chlorophyll content of alfalfa leaves was noted after exposing the whole plant to microwave irradiation [56]. Asghar et al. [57] conducted an experiment on the impact of various magnetic field parameters and laser light on the content of chlorophylls $(a, b, a+b)$, and reported a significant increase in that pigment's concentration under all studied treatments, relative to the control.

The ratio of chlorophyll $a$ to chlorophyll $b$ was approximately 3:1, irrespective of cultivar or plant age (old and young plants). The content of carotenoids was notably higher in cv. Ulstar as compared to cv. Radius. The level of that pigment was also significantly higher in young alfalfa when compared to older plants.

In a study by Huang et al. [50], the $a / b$ chlorophyll ratio was estimated to vary between 1.56 and 1.80 , depending on light intensity. Nozue et al. [51] observed that the $a / b$ chlorophyll ratio for Arabidopsis thaliana ecotype Columbia was ca. 3.5 for young plants, and approx. 2.8 for old plants.

Leaf ageing causes a decrease primarily in chlorophyll $a$ levels [58]. In the study presented herein a similar correlation was observed. In old plants, the content of chlorophyll $a$ decreased significantly relative to young plants, irrespective of other factors.

In old cv. Radius plants an increase in mean fluorescence lifetimes was observed (Table 1), accompanied by elevated chlorophyll $a$ content (Table 2) relative to the control, regardless of the applied combinations of physical factors, although the differences were significant only in the case of alternating magnetic field treatment $(\mathrm{P})$. In the case of cv. Ulstar (old plants), the opposite was observed (i.e., the parameter decreased). The obtained results in terms of fluorescence lifetimes in old cv. Radius plants clearly 
indicated good condition of the plants, as well as their high resistance to stress factors [23, 27].

Light plays a vital part in the growth and development of plants, but as observed in a study by Ma et al. [59], increased insolation of rice leaves had a negative effect on the process of photosynthesis. Excessive sunlight causes irreparable damage to the plant $[28,59]$.

To recapitulate, the variable content of photosynthetic pigments is conditioned by numerous stress-inducing factors (draught, excessive insolation) [28, 60] as well as, primarily, the plant species as such and the local climate [19].

\section{Conclusions}

1. The electromagnetic stimulation applied in the study had an effect on the duration of mean fluorescence lifetimes. In the case of cv. Radius plants, old, the observed decay times were shorter relative to cv. Ulstar, old, and young alfalfa plants. Under the effect of electromagnetic stimulation, an increase was achieved in terms of the mean fluorescence lifetimes and chlorophyll a content in old cv. Radius plants relative to the control, which confirms the good physiological status of the analysed plants.

2. Electromagnetic factors significantly differentiated the concentrations of chlorophylls $a$ and $b$ between the particular cultivars, as well as between young and old plants. An increase in chlorophyll $a$ concentration due to physical factors was observed only in old cv. Radius plants.

3. An increase in chlorophyll $b$ content (by ca. 20\%) was observed only under the alternating magnetic field treatment in old cv. Radius plants.

4. The chlorophyll $a$ to chlorophyll $b$ ratio varied between 2.95 and 3.23. Compared to the control treatment, the electromagnetic factors caused an increase in the value of that ratio in the studied cultivars.

5. Under the effect of physical seed stimulation, a significant increase in carotenoid content was observed only in cv. Radius plants (old) stimulated with electromagnetic field, while under the remaining treatments, the stimulating factors caused a decrease in carotenoid concentration. The 2-year-old plants were generally characterised by significantly higher carotenoid content when compared to 6-year-old plants.

\section{Acknowledgements}

The authors wish to thank Prof. Leszek Fiedor, Jagiellonian University, Krakow, for providing them with access to a Chronos BH spectrofluorometer (ISS, USA).

\section{Conflict of Interest}

The authors declare no conflict of interest.

\section{References}

1. DZIWULSKA-HUNEK A., KORNARZYŃSKI K., MATWIJCZUK A., PIETRUSZEWSKI S., SZOT B. Effect of laser and variable magnetic field simulation on amaranth seeds germination. International Agrophysics 23, 229, 2009.

2. HERNANDEZ A.C., DOMINGUEZ P.A., CRUZ O.A., JVANOV R., CARBALLO C.A., ZEPEDA B.R. Laser in agriculture. International Agrophysics 24, 407, 2010.

3. MARTÍNEZ E., FLÓREZ M., MAQUEDA R., CARBONELL M.V., AMAYA J.M. Pea (Pisum sativum L.) and lentil (Lens culinaris Medik) growth stimulation due to exposure to 125 and $250 \mathrm{mT}$ stationary fields. Polish Journal of Environmental Studies 18, 657, 2009.

4. NIMMI V., MADHU G. Effect of pre-sowing treatment with permanent magnetic field on germination and growth of chilli (Capsicum annum L.). International Agrophysics 23, 195, 2009.

5. ĆWINTAL M., DZIWULSKA-HUNEK A. Effect of electromagnetic stimulation of alfalfa seeds. International Agrophysics 27, 391, 2013.

6. DZIWULSKA-HUNEK A., KRAWIEC M., SUJAK A. Laser light stimulation effects on Scorzonera hispanica L. seeds germination, filed emergence and photosynthetic pigments content. Journal of Horticultural Research 24 (1), 57, 2016.

7. MATWIJCZUK A., KORNARZYŃSKI K., PIETRUSZEWSKI S. Effect of magnetic field on seed germination and seedling growth of sunflower. International Agrophysics 26, 271, 2012.

8. POINAPEN D., BROWN D.C.W., BEEHARRY G.H. Seed orientation and magnetic field strength have more influence on tomato seed performance than relative humidity and duration of exposure to non-uniform static magnetic fields. Journal of Plant Physiology 170, 1251, 2013.

9. SACAŁA E., DEMCZUK A., GRZYŚ E., PROSBABIAŁCZYK U., SZAJNER H. Impact of pre-sowing laser irradiation of seeds on sugar beet properties. International Agrophysics 26, 295, 2012.

10. GOŁAWSKA S., ŁUKASIK I., GOŁAWSKI A., KAPUSTA I., JANDA B. Alfalfa (Medicago sativa L.) Apigenin Glycosides and Their Effect on the Pea Aphid (Acyrthosiphon pisum). Polish Journal of Environmental Studies 19 (5), 913, 2010.

11. OFFICIAL JOURNAL OF THE EUROPEAN UNION. L 294, 11.11.2009, 52, 12, 2009.

12. ANOWER M.R., MOTT I.W., PEEL M.D., WU Y. Characterization of physiological responses of two alfalfa half-sib families with improved salt tolerance. Plant Physiology and Biochemistry 71, 103, 2013.

13. RECHULICZ J., OGNIK K., GRELA E.R. The Effect of Adding Protein-Xanthophyll Concentrate (PX) from Lucerne (Medicago sativa) on Growth Parameters and Redox Profile in Muscles of carp, Cyprinus carpio (L.) Turkish Journal of Fisheries and Aquatic Sciences 14, 697, 2014.

14. SUJAK A., DZIWULSKA-HUNEK A., RESZCZYŃSKA E. Effect of Electromagnetic Stimulation on Selected 
Fabaceae Plants. Polish Journal of Environmental Studies 22 (3) 893, 2013.

15. ZHANG W., GRIMI N., JAFFRIN M.Y., DING L. Leaf protein concentration of alfalfa juice by membrane technology. Journal of Membrane Science 489, 183, 2015.

16. MOURADI M., BOUIZGAREN A., FARISSI M., LATRACH L., OADDOURY A., GHOULAM CH. Seed osmopriming improves plant growth, nodulation, chlorophyll fluorescence and nutrient uptake in alfalfa (Mediacgo sativa L.) - rhizobia symbiosis under drought stress. Scientia Horticulturae 213, 232, 2016.

17. REKIK I., CHAABANE Z., MISSAOUI A., BOUKET A.CH., LUPTAKOVA L., ELLEUCH A., BELBAHRI L. Effects of untreated wastewater at the morphological, physiological and biochemical levels on seed germination and development of sorghum (Sorghum bicolor L. Moench), alfalfa (Medicago sativa L.) and fescue (Festuca arundinacea Schreb.). Journal of Hazardous Materials 326, 165, 2017.

18. LI L., LI X.Y., ZENG F.J., LIN L.S. Chlorophyll a fluorescence of typical desert plant Alhagi sparsifolia Shap. at two light levels. Photosynthetica 54 (3), 351, 2016.

19. NOVICHONOK E.V., NOVICHONOK A.O., KURBATOVA J.A., MARKOVSKAYA E.F. Use of the at $L E A F+$ chlorophyll meter for a non-destructive estimate of chlorophyll content. Photosynthetica 54 (1), 130, 2016.

20. SÁNCHEZ C., BARANDA A.B., MARTÍNEZ D.E., MARAÑ́N I. The effect of High Pressure and High Temperature processing on carotenoids and chlorophylls content in some vegetables. Food Chemistry 163, 37, 2014.

21. ROTKIEWICZ D., KONOPKA I., TAŃSKA M. Carotenoid and chlorophyll pigments of vegetable oils and their functions (in Polish). Rośliny Oleiste XXIII, 561, 2002.

22. VREDENBERG W., PRÁŠIL O. Modeling of Chlorophyll a Fluorescence Kinetics in Plant Cells: Derivation of a Descriptive Algorithm. Photosynthesis in silico: Understanding Complexity from Molecules to Ecosystem A. Laisk, L. Nedbal and Govindjee (eds.). 125, 2009.

23. CETNER M.D., DĄBROWSKI P., SAMBORSKA I.A., ŁUKASIK I., SOWCZYNA T., PIETKIEWICZ S., BĄBA W., KALAJI H.M. Application of chlorophyll fluorescence measurements in environmental studies (in Polish). Kosmos Problemy Nauk Biologicznych. Polskie Towarzystwo Przyrodników im. Kopernika 65 (2), 197, 2016.

24. STARCK Z. Plant physiology: what was yesterday, what is today, and will happen tomorrow? (in Polish). Kosmos Problemy Nauk Biologicznych. Polskie Towarzystwo Przyrodników im. Kopernika. 63 (4), 569, 2014.

25. DJUKIĆ M., DJUNISIJEVIĆ-BOJOVIĆ D., PAVLOVIĆ P., MITROVIĆ M., GRBIĆ M., SKOČAJIĆ D., LUKIĆ S. Influence of Fe Nutrition on Photosynthesis in $\mathrm{Pb}$ Treated Ailanthus altissima (Mill.) Swingle Seedlings. Polish Journal of Environmental Studies 23 (5), 1565, 2014.

26. LAKOWICZ J.R. Principles of Fluorescence Spectroscopy. $3^{\text {rd }}$ edition, Spronger Science+Business Media LLC, New York, USA 2006.

27. BAKER N.R., ROSENQVIST E. Applications of chlorophyll fluorescence can improve crop production strategies: an examination of future possibilities. J Exp Bot 55, 1607, 2004.

28. HAZRATI S., TAHMASEBI-SARVESTAN Z., MODARRES-SANAVY S.A.M., MOKHTASSI-BIDGOLI A., NICOLA S. Effects of water stress and light intensity on chlorophyll fluorescence parameters and pigments of
Aloe vera L. Plant Physiology and Biochemistry 106, 141, 2016.

29. HOUBORG R., MCCABE M.F., CESCATTI A., GITELSON A.A. Leaf chlorophyll constraint on model simulated gross primary productivity in agricultural systems. International Journal of Applied Earth Observation and Geoinformation 43, 160, 2015.

30. SEVIK H., CETIN M. Effects of Water Stress on Seed Germination for Select Landscape Plants. Polish Journal of Environmental Studies 24 (2), 689, 2015.

31. TURKYILMAZ A., SEVIK H., CETIN M., AHMAIDA SALEH E.A. Changes in Heavy Metal Accumulation Depending on Traffic Density in Some Landscape Plants. Polish Journal of Environmental Studies 27 (5), 2277, 2018.

32. YIGIT N., SEVIK H., CETIN M., KAYA N. Chapter 3: Determination of the effect of drought stress on the seed germination in some plant species. Water Stress in Plants, Intech Open, Eds: Ismail Md. Mofizur Rahman, Zinnat Ara Begum, Hiroshi Hasegawa, 43, 2016.

33. KRAVKAZ KUSCU I.S.., CETIN M., YIGIT N., SAVACI G., SEVIK H. Relationship between Enzyme Activity (Urease-Catalase) and Nutrient Element in Soil Use. Polish Journal of Environmental Studies 27 (5), 2107, 2018

34. SEVIK H., CETIN M., KAPUCU O., BARICAK B., CANTURK U. Effects of light on morphologic and stomatal characteristics of turkish fir needles (abies nordmanniana subsp. bornmulleriana mattf.), Fresenius Environmental Bulletin 26 (11), 6579, 2017.

35. CETIN M., SEVIK H., YIGIT N., OZEL H.B., ARICAK B., VAROL T.(). The variable of leaf micromorphogical characters on grown in distinct climate conditions in some landscape plants. Fresenius Environmental Bulletin 27 (5), 3206, 2018.

36. CETIN M., ZEREN I., SEVIK H., CAKIR C., AKPINAR H. A study on the determination of the natural park's sustainable tourism potential. Environmental Monitoring and Assessment 190 (3), 167, 2018.

37. CETIN M., SEVIK H., CANTURK U., CAKIR C. Evaluation of the recreational potential of Kutahya urban forest. Fresenius Environmental Bulletin 27 (5), 2629, 2018.

38. GUNEY K., CETIN M., GUNEY K.B., MELEKOGLU A. The Effects of Some Hormone Applications on Lilium martagon L. Germination and Morpholgical Characters. Polish Journal of Environmental Studies 26 (6), 2533, 2017.

39. CETIN M., SEVIK H., SAAT A. Indoor Air Quality: the Samples of Safranbolu Bulak Mencilis Cave. Fresenius Environmental Bulletin 26 (10), 5965, 2017.

40. CETIN M. Chapter 27: Landscape Engineering, Protecting Soil, and Runoff Storm Water, InTech-Open ScienceOpen Minds, Online July $1^{\text {st }}$, 2013. Book: Advances in Landscape Architecture-Environmental Sciences 697, 2013.

41. KOPER R., DYGDAŁA Z. System used in presowing laser light biostimulation of seeds. Patent Office of Republic of Poland, no. 162598, WUPRP 12, 1111, 1993 [In Polish].

42. MUSZYŃSKI S., GAGOŚ M., PIETRUSZEWSKI S. Short-Term Pre-Germination Exposure to ELF Magnetic Field Does Not Influence Seedling Growth in Durum Wheat (Triticum durum). Polish Journal of Environmental Studies 18 (6), 1065, 2009.

43. LICHTENTHALER H.K., BUSCHMANN C. Chlorophylls and Carotenoids: Measurement and Characterization by UV-Vis Spectroscopy. In: Current 
Protocols in Food Analytical Chemistry. Supplement 1, Wiley \& Sons. Inc., USA:F4.3.1, 2001.

44. SCHURR U., WALTER A., RASCHER U. Functional dynamic of plant growth and photosynthesis - from steady state to dynamics - from homogeneity to heterogeneity. Plant, Cell and Environment 29, 340, 2006.

45. SOWINSKA M., HEISEL F., MIEHE J.A., LANG M., LICHTENTHALER H.K., TOMASINI F. Remote sensing of plants by streak camera lifetime measurements of the chlorophyll $a$ emission. Journal Plant Physiology 148, 638, 1996.

46. LEI R., JIANG H., HU F., YAN J., ZHU S. Chlorophyll fluorescence lifetime imaging provides new insight into the chlorosis induced by plant virus infection. Plant Cell Rep, 36, 327, 2017.

47. NOBLE E., KUMAR S., GÖRLITZ F.G., STAIN CH., DUNSBY CH., FRENCH M.W. In vivo label-free mapping of the efect of a photosystem II inhibiting herbicide in plants using chlorophyll fuorescence lifetime. Plant Methods 13 (48), 1, 2017.

48. CETIN M. Change in Amount of chlorophyll in some interios ornamental plants. Kastamonu University Journal of Enigineering and Sciences 3 (1), 11, 2017.

49. SINGH S.K., REDDY V.R., FLEISHER D.H., TIMLIN D.J. Relationship between photosynthetic pigments and chlorophyll fluorescence in soybean under varying phosphorus nutrition at ambient and elevated $\mathrm{CO}_{2}$. Photosynthetica 55 (3), 421, 2017.

50. HUANG D., WU L., CHEN J.R., DONG L. Morphological plasticity, photosynthesis and chlorophyll fluorescence of Athyrium pachyphlebium at different shade levels. Photosynthetica, 49 (4), 611, 2011.

51. NOZUE H., OONO K., ICHIKAWA Y., TANIMURA S., SHIRAI K., SONOIKE K,. NOZUE M., HAYASHIDA N. Significance of structural variation in thylakoid membranes in maintaining functional photosystems during reproductive growth. Physiologia Plantarum 160, 111, 2017.

52. MROCZEK-ZDYRSKA M., KORNARZYŃSKI K., PIETRUSZEWSKI S., GAGOŚ M. Stimulation with a 130-mT magnetic field improves growth and biochemical parameters in lupin (Lupinus angustifolius L.). Turkish Journal of Biology 40, 699, 2016.

53. NOWAK A., WRÓBEL J. Effect of exogenic growth regulators on the content of assimilative pigments in leaves of three cultivars of common soybean (Glycine max L. Merr). Rośliny oleiste-Oilseed Crops XXX, 352, 2010 [In Polish].

54. TAÏBI K., TAÏBI F., ABDERRAHIM L.A., ENNAJAH A., BELKHODJA M., MULET J.M. Effect of salt stress on growth, chlorophyll content, lipid peroxidation and antioxidant defence systems in Phaseolus vulgaris L. South African Journal of Botany 105, 306, 2016.

55. KHALID M., BILAL M., HASSANI D., IQBAL H.M.N, WANG H., HUANG D. Mitigation of salt stress in white clover (Trifolium repens) by Azospirillum brasilense and its inoculation effect. Botanical Studies 58, 1, 1, 2017.

56. SKILES J.W. Plant response to microwaves at $2.45 \mathrm{GHz}$. Acta Astronautica 58, 258, 2006.

57. ASGHAR T., JAMIL Y., IQBAL M., ZIA-UL-HAQ, ABBAS M. Laser light and magnetic field stimulation effect on biochemical, enzymes activities and chlorophyll contents in soybean seeds and seedlings during early growth stages. Journal of Photochemistry \& Photobiology B:Biology 165, 283, 2016.

58. GAO S., GAO J., ZHU X., SONG Y, LI Z., REN G., ZHOU X., KUAI B. ABF2, ABF3, and ABF4 Promote ABAMediated Chlorophyll Degradation and Leaf Senescence by Transcriptional Activation of Chlorophyll Catabolic Genes and Senescence-Associated Genes in Arabidopsis. Molecular Plant 9, 1272, 2016.

59. MA J., LV CH., XU M., HAO P., WANG Y., SHEN W., GAO Z., CHEN G., LV CH. Analysis of chlorophyll a fluorescence and proteomic differences of rice leaves in response to photooxidation. Acta Physiol Plant 39 (46), 1, 2017.

60. GAMEIRO C., UTKIN A.B., CARTAXANA P., MARQUES DA SILVA J., MATOS A.R. The use of laser induced chlorophyll fluorescence (LIF) as a fast and non-destructive method to investigate water deficit in Arabidopsis. Agricultural Water Management 164, 127, 2016. 